\title{
Democratizing Electricity in Nepal: NACEUN is Lighting up one Community at a Time
}

\section{Trishna Rana}

T he state's failure to provide Nepalese with reliable source of electricity becomes most apparent during the peak months of winter. With load shedding season in full swing Nepalese are being forced to spend countless hours in the dark. However, the fact of the matter is that a large segment of the population has always been without electricity. Outside the major cities, life in rural Nepal comes to a halt every time the sun goes down.

Although the Nepal Electricity Authority (NEA) is still a long way from connecting remote corners of the country to the national grid, local electricity consumer groups have taken the initiative to light up their communities through grid extended electricity. And the National Association of Community Electricity Users Nepal (NACEUN), established in 2005, has been at the forefront of the campaign of democratizing electricity in the nation.

The rural electrification movement was first taken off before May 2003 when the NEA board passed the Community Electrification Distribution Bylaws, 2060 (2003 AD). Consumer initiatives were started since 1996 for their village electrification as a momentum to get reliable and affordable electricity and contributing to democratisation to Nepali power sector. Learning from community's experiences and positive impact NEA formulated community based electricity distribution by law to formal handshake with rural community for participation in rural electrification process, capital cost sharing and distribution management of grid based electrification. This bylaw allowed community and user groups to purchase electricity from the NEA and determined that 80 percent of the cost would be covered by the government, while the community contributed the remaining 20 percent (it has been changed to 90:10 since 2011). Under this agreement, not only are communities solely responsible for the management, maintenance and distribution of electricity, but they also get to retain all the profit.

At the time NACEUN came into existence, 70 percent of rural Nepal was not covered. In 6 short years, the organization has managed to bring electricity to 1,98,344 rural households and another 107,00o households are in different stages of the process; some near connection, others under construction, while many more still in the pipeline. The speed at which NACEUN has reached communities is almost double the rate at which NEA has been working.

The reason behind the organization's success is that rather than the top-down approach practiced by government agencies, NACEUN follows the consumer based movement approach which is bottom up and acts as the representative of hundreds of electricity user groups, cooperatives and committees throughout the nation.

Currently, NACEUN has 217 members in 47 districts and it provides them with technical assistance and expertise, lobbies for new legislation and advocates the members' interests with policy makers. It is also engaged in institutional development, end use promotion of electricity and capacity building activities. But on the grassroots level, bulk of the work is done by community members themselves thus making it a truly participatory venture.

So far rural electrification has yielded numerous positive results in the fields of agriculture, rural industries, education, health, transportation, communication. Household and small-scale industries in particular have gotten a much needed impetus, children in rural schools are finally able to use technologies like computers, telephone lines have been built, villagers in remote village can recharge their mobile phones and health posts can refrigerate vaccines and medicines. In addition, direct employment opportunities for 1100 villagers have been generated across the country. Now community rural electrification has been main-stream of Nepali rural electrification.

Another indication of the success of community-run electrification programs is that administration has been very efficient and pilferage is absent. NACEUN is hopeful that in the next 10 years the community electrification projects will successfully connect most households to the national grid and Nepalese will no longer have to live in darkness. However, NACEUN and its members will need the continual support of NEA and the government.

Corresponding address of author: trishna.rana@gmail.com

\section{Reference}

Nepal electricity authority (NEA) Community Electrification Distribution Bylaws, 2060 (2003). 


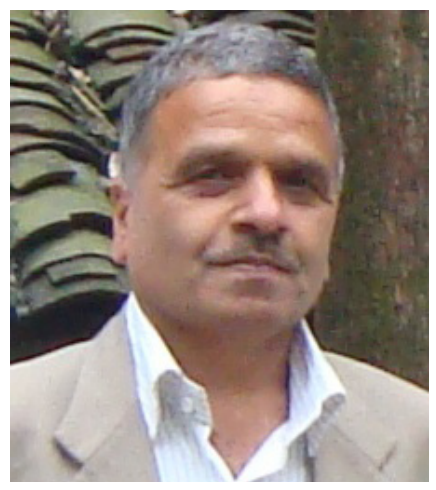

Mr. Dilli Prasad Ghimire, Chairman of NACEUN, was born in Lalitpur, Nepal in 1961. He completed his Bachelor Degree from Tribhuvan University (TU) and joined Government and Non-governmental services for 16 years since 1985. His hometown Lalitpur, which is not far away from Kathmandu, had no electricity then. Realizing that it might take many years for NEA to connect South Lalitpur to the national grid, and micro hydro and pico hydropower was not a sustainable solution; Ghimire left his job with International Non-governmental Organization and started initiatives for South Lalitpur Rural Electrification Movement as loose forum in 1997. Now it has been transformed as South Lalitpur Rural Electric Cooperative since 1997. The cooperative managed access of electricity to 19 VDCs of South Lalitpur where 4,100 households have access to electricity services/ access in the area. Sixteen people are employed in this cooperative. It is a milestone development to have access to electricity in the area.

Mr. Ghimire has been active in advocating for access to affordable and sustainable energy to Nepalese; even in the most rural areas. He has worked relentlessly to forge political consensus and come up with solutions to Nepal's electricity crisis. He established NACEUN in 2005 with the aim of bring together various electricity user groups, cooperatives and committees across the country into a national network.

Past year, Mr. Ghimire published a book in Nepali Language named Grameen Bidhutikaranma Samudayik Sahabhagita (Community Participation in Rural Electrification) recounting his more than 20 years of hands on experience in the field.

\section{CALENDAR OF EVENTS - ENERGY}

24-25 February, 2012: Renewable Energy Solutions. Location: Edinburgh Napier University, UK. More info: www.euenergycentre.org/training/training-courses/114renewable-energy-solutions.

27-29 February, 2012: 2nd International Conference on Energy, Environment, and Sustainable Development (EESD-2012). Location: Jamshoro, Sindh, Pakistan. More info: www.muet.edu.pk/eesd2012.

29 February to 2 March, 2012: Australia's First Energy Efficiency 'Summer Study'. Location: Sydney, Australia. More info: www.a2se.org.au.

13-15 March, 2012: 7th Annual World Biofuels Markets, Location: Rotterdam, Netherlands. Contact Email: info@greenpowerconferences.com. More info: www. worldbiofuelsmarkets.com.

28-30 March, 2012: International Conference on Renewable Energies and Power Quality sponsored by European Association for the Development of Renewable Energy, Environment and Power Quality. Location: Santiago de Compostela, Spain. More info: www.icrepq. com.

29-31 March 2012: CEP $囚$ Clean Energy \& Passive House 2012. Location: Stuttgart, Germany. More info: www.cepexpo.de/kongress.html?\&L=1

4-5 April, 2012: Solar West Africa 2012. Location: Accra, Ghana. More info: www.solarwestafrica.com/

4-5 April, 2012: International Congress on Energy Security. Location: Geneva, Switzerland. More info: http:// energysecuritycongress.com.

19-21 April, 2012: Renewable Energy World India sponsored by PennWell Corporation. Location: New Delhi, India. Contact Email: amyn@pennwell.com. More info: www.renewableenergyworldindia.com.
19-21 April, 2012: POWER-GEN India and Central Asia sponsored by PennWell Corporation. Location: New Delhi, India. Contact Email: samantham@pennwell.com. More info: www.power-genindia.com.

3-6 May, 2012: The Second Asian Conference on Sustainabilty, Energy and the Environment (ACSEE 2012). Location: Osaka, Japan. More info: www.acsee. iafor.org/.

10-12 May, 2012: Workshop Renewable Energy, Environment, Sustainable Development and NTICs Casamansun 2012. Location: Ziguinchor, Senegal, Senegal. More info: www.sites.google.com/site/ casamansunenr2012/.

23 - 24 May, 2012: All-Energy 2012. Location: NEC, Birmingham. More info: www.all-energy.co.uk/.

27 May to 1 June, 2012: IAIA12 Energy Future: The Role of Impact Assessment. Location: Porto, Portugal. More info: iaia.org/conferences/iaia12/.

6-7 June, 2012: GeoPower Indonesia \& Philippines. Location: Jakarta, Indonesia. Contact Email: samantha. coleman@greenpowerconferences.com. More info: www. greenpowerconferences.com.

13-14 June, 2012: European Biodiesel 2012. Location: Krakow, Poland. Contact Email: cwilliams@acieu.net, More info: www.wplgroup.com/aci/conferences/eu-eaf5. asp.

1-6 July, 2012: The 7th Conference on Sustainable Development of Energy, Water and Environment Systems - SDEWES Conference Ohrid 2012. Location: Ohrid, Macedonia More info: www.ohrid2012.sdewes.org/.

10-12 September, 2012: ICCE 2012: International Conference on Clean Energy. Location: Quebec, Canada. More info: www.iaemm.com/ICCE_Home/. 